\title{
Fostering Innovation in the National Systems: An Application to Spain
}

\author{
Carmen de Pablos Heredero \\ Rey Juan Carlos University, Spain \\ Jose Manuel Bermejo Ruiz \\ FringesCT, Spain
}

\section{Abstract}

Background: The sharing of practices that enable the flow and the distribution of tacit knowledge and other ways of proprietary knowledge are essential requisites for promoting an innovation system. Objectives: In this paper a diagnosis of the Spanish Science and Technology System is offered by using the normalized protocol for responsible partnering proposed by EIRMA. Methods/Approach: The triple helix model has been used to identify the agents that take part in the system. The grounded theory has also been applied to analyse interactions and interviews with seven key agents in the system. Results: The lack of common objectives among the main partners in the system is the most important weakness; the New Acts developed in the last three years is a strength that allows the different agents of the system to share objectives. The economic crisis is a threat for the performance of research within the university context and becomes at the same time an opportunity to establish closer relationships. Conclusions: Universities, firms and governments must synchronise their work to accomplish a common objective: produce high levels of innovation that aim to enhance the competitiveness of the system.

Keywords: open innovation practices; science and technology system; EIRMA; transfer of knowledge; grounded theory; stakeholders

JEL main category: $M$

JEL classification: M1, M2

Paper type: Research article

Received: 2, October, 2013

Accepted: 16, May, 2014

Citation: de Pablos Heredero, C., Bermejo Ruiz, H.M. (2014). "Fostering Innovation in the National Systems: An Application to Spain", Business Systems Research, Vol. 5, No. 2, pp. 110-124.

DOI: $10.2478 /$ bsrj-2014-0014

Acknowledgements: We would like to acknowledge the active participation in the Delphi analysis to the following firms: Bioserentia, Cotec Foundation, Madrid Polytechnic University (UPM-Indra Project, Telefonica R+D, Technalia, Aimen and Genoma Spain Foundation. 


\section{Introduction}

Some countries are characterized by the great number of scientific production and the lack of capacity for the creation of value in terms of innovation (Drucker, 1994; Conner, Prahalad, 1996; Galán, Casanueva, Castro-Abancéns, 2010). This circumstance has a negative impact in the competitiveness of the country in the international context.

Innovations are a result of a process of development and learning that goes beyond the organizational barriers, from the scientific and technological developments up to those that appear from the interaction with other sources of knowledge. These interactions have the power to make dynamic capabilities appear (Senge, 1990; Teece, Pisano, Shuen, 1997; Eisenhardt, Martin, 2000; Zollo, Winter, 2002) and this reality is directly related with the concept of relational capital and its positive influence over organizational innovation (Srivastava, Fahey, Christensen., 2001; Castro et al., 2009).

The triple helix model (Etzkowitz, Leydesdorff, 2000) shows that the efficiencies in the national system of innovation are promoted through the common goal orientation of the universities, industries and governments. But in real world there exists a coordination gap between the enterprise, academics and scientists, and the lack of alignment among their objectives is an important obstacle for reaching efficiencies in the higher education system. The university can play a key role in improving such alignment and narrowing the gap between these institutions, as it is one of the major elements in our society for promoting not only the knowledge and innovation but also the successful inter organizational relationships (De Pablos Heredero et al., 2012).

In this sense, we can stress that organizations in a certain environment can combine resources in order to establish networks that favour and stress some interorganizational links, as it is proposed by regional and national innovation systems (Malerba, 2002, 2004). In these systems the identification of agents and relationships (Fleming, Sorenson, 2004, Quintero Campos, 2010; Bermejo Ruiz, De Pablos Heredero, 2013) serve as a basis for the creation and spread of knowledge and greatly influence as a foundation for the development of innovation policies (Lundvall, 1992).

Changes in the innovation model have evolved due to the action of a series of external factors that have been leaders in the change of paradigm shown in next table. Amongst these factors it is found the globalization, the global collaboration processes and social transformations (Bermejo Ruiz, 2012).

- Globalization: The International Monetary Fund (1997) describes the existence of a group of factors that promote the integration of the world economy: 1. the technological advances as the ones that have taken place in transport, communications and computing that allow firms to coordinate the production activities located in different places and enable the spread of technological innovations and specialized knowledge. 2. The economic policies have decreased the artificial barriers in the circulation of goods, services and capital. Institutions as Bretton Woods, the Organization for the Economic Cooperation Development (OECD) and the World Organization of Commerce help an important number of countries adopt open market economic systems.

- Global collaboration processes: The establishment of global networks composed by different partners that contribute with their knowledge and other abilities to the execution of projects (Artopoulos, 2006). McCormack, et al. (2007) by analyzing the corporate collaboration processes at organizations determined 
that the investment in the development of these collaborative practices produced competitive advantages.

- Social transformations: One of the main merits of information and communication technologies and particularly from Internet is the capacity to produce knowledge. For the first time the authority of an economic revolution keeps in the population itself, and this is the main aspect that distinguishes this revolution from another previous one (Benkler, 2002, 2005).

The concept of production amongst similar agents, commons-based peer production (Benkler, 2006) describes a new economic model of production where the creative energy of a great number of people is coordinated in a Project far from the traditional hierarchical schemas in an Organization and by making use of Internet as the main communication channel.

The existing literature on the determinants of R\&D cooperation is mainly focused on organization specific factors to study the motives of cooperation among organizations and how these motives alter the initial settings and outcomes (Hagerdoorn, 1993, Chung, Singh, Lee, 2000, Haider, De Pablos Heredero, 2012). These studies are mainly focused in the main conditions that from the organizational point of view determine the interaction among R\&D partners (Doz, Olk, Ring, 2000). However, the characteristics that are centred on the institutional factors where such interactions happen are still considered less significant (Werger, 2003). Therefore, to transform the scientific production in innovation requires of an institutional effort that will foster the creation of areas of interchange between the academia and the market (Tognato, 2007) that promote the private and public initiatives for collaboration.

The dichotomy that we find in some parts of the European Science and Technology System, that it is one of the longest-running European frameworks supporting cooperation among scientists and researchers across Europe, showing high levels of scientific production and low levels in innovation and competitiveness, lead us to think that the relationships that the system maintain are not based in the sharing of objectives amongst the different agents that take part and this reality acts as a detractor element to establish a model where the university, the industry and the government collaborate to reach common objectives and this way build a system where efficiency is maximized, as it is proposed by the triple helix model (Etzkowitz, Leydesdorff, 2000).

The main objective of this article consists of applying a Delphi method based in the use of the grounded theory methodology (Glaser, Strauss, 1967), to offer a realistic diagnosis of the interests that each agent being part of the Spanish Science and Technology system shows to this respect. By applying the EIRMA European Industrial Research Management Association protocol, EIRMA (2009) we will offer a diagnosis of the Spanish system that make serve as an example in the international context.

This protocol is based in the assumption that the organizations must approve and adopt Responsible Partnering Practices (EIRMA, 2009). The Organization in charge of a project offers the path so that the different agents coming from the Public and Private Industries can contribute by considering the success of the research and collaborate in the improvement of the structure according to their own experiences.

The questions are aimed to know if the joint collaboration agreements are adapted to the methodology agreed in the European Industry and shown in the good practices protocol published by the EIRMA, where the different aspects that appear in the public-private consortium are considered. 


\section{Methodology}

\section{Background}

To identify the agents that take part in the Spanish Innovation System, the triple helix model (Erkowitz, Leydesdorff, 2000; Bermejo Ruiz, 2012) has been used. This approach has allowed the identification of the agents and the relations established amongst them. In figure 1 we present the main actors of the system.

Figure 1

The triple helix model applied to the Spanish model of Science and Technology

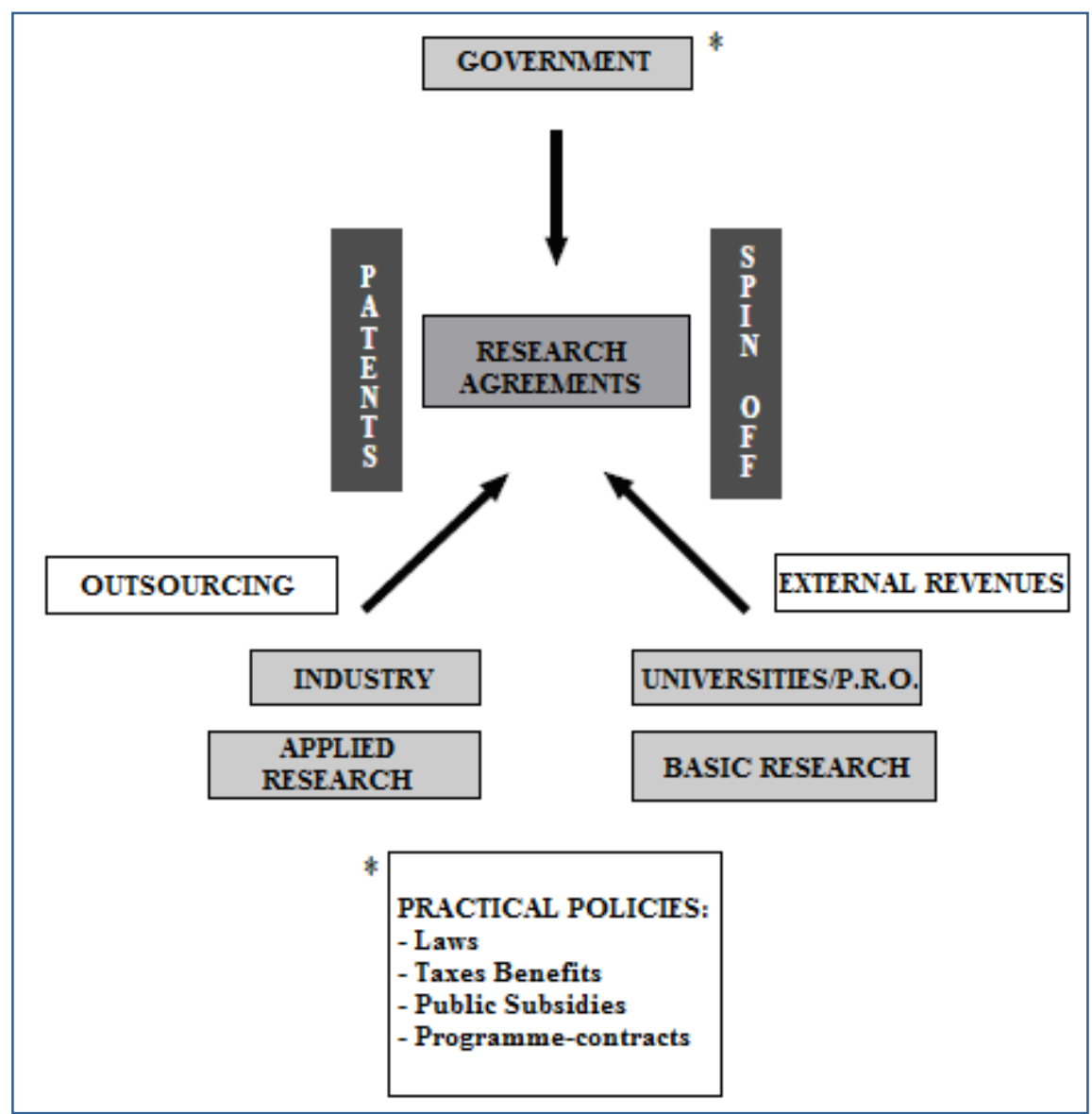

Source: Bermejo Ruiz (2012)

\section{Grounded theory approach}

We are going to use the inductive-deductive method based in the observation of the reality with the main objective to reach a generalized consensus, and if possible a model of behaviour. By making use of the grounded theory we have identified the different agents, analyzed interactions, studied the legal framework and afterwards we have realized interviews in deep with national experts in the University system. The grounded theory allows us explaining the relations in the various human beings behaviours in a concrete field of study.

The grounded theory is a qualitative method of research that tries to build theories from data collected in real scenarios (Myers et al., 2009). It is an inductive method that allows the production of emergent theories where some knowledge gaps are identified. This methodology specially applies for descriptions centred in a context where organizational phenomena appear (Goldkuhl, 2004). The grounded theory 
has first been applied to psychology (Glaser, Strauss, 1967; Strauss, Corbin, 1990) and later in the information systems area (Orlikowski, Robey, 1991; Orlikowski, 1993) including our area of interest, the research in innovation systems (Dedrick, West, 2005).

Some researchers that have studied the processes for technology innovation (Venkatesh et al., 2003; Al-Natour, Benbasat, 2009) have stressed the importance for modeling the user's behaviour. For this work we need a wider perspective. The analysis of opportunities and threats in innovation systems is going to have impacts in wide business areas and many different stakeholders can benefit from it, amongst others the final customers of innovative products and services.

Therefore, for our analysis an organizational approach is required. This approach demands not only quantitative approaches such as (Gonzalez-Barahona et al., 2001; Wheeler, 2007) but also positivistic ones since we lack hypothesis around the system. Contrary to other approaches, theory is being built as data are being processed. We believe that both, the firm's level and the macro analysis are complemented when trying to find a global perspective that explains the progressive change in innovation systems.

Although traditionally this methodology has been applied to sociological studies, there are some other areas of knowledge that have used it in innovation areas (Lowe, 1995), the director's perspective (Partington, 2000), the research in business organization (Locke, 2001), the creation of firms (Douglas, 2009) or innovation systems (Douglas, 2003).

Glaser (1992) affirms that the grounded theory is useful to do research in fields related with human behaviour in different organizations, groups and other social configurations. Since the context to create a science and technology system is a social process, we can affirm that this methodology can be applied to the study itself (Douglas, 2003).

To achieve the objective of the research we will develop case studies in deep by considering a representative sample of agents that take part in the Science and Technology system of the country included in this work.

\section{Case studies}

From a study of cases we have identified different models for the promotion of collaborative practices amongst the University and firms. The study analyzed is composed by multiple cases. The selection of the cases has been provided according to two main criteria:

1. The heterogeneity, all the selected cases are linked to the different Spanish Science and Technology sub-Systems.

2. The exemplarity, the organizations we analyze in Spanish context are exemplar and take an active part in the development of a competitive science and technology system.

Table 1 shows the different cases analyzed.

The need for coordination: the application of a Delphi analysis

The need of coordination is a pre-requisite to reach good results at Science Systems. Coordination is the integration of organizational work in conditions of task and uncertain interdependence. The model of relational coordination puts emphasis in understanding the importance of coordinating the relationships and the dynamics of communication in organizations to reach best results (Gittell, 2009). From the model 
we can affirm that relational coordination is produced by providing a frequent communication of high quality, supported in shared objectives and knowledge and mutual respect.

Table 1

The cases selected for the research

\begin{tabular}{|l|l|}
\hline \multicolumn{1}{|c|}{ Firm } & \multicolumn{1}{|c|}{ Main activity } \\
\hline Bioserentia & $\begin{array}{l}\text { Business foundation composed by } 69 \text { public and private } \\
\text { institutions with the main mission of promoting } \\
\text { technological innovation }\end{array}$ \\
\hline $\begin{array}{l}\text { Mcademic Institution representing the public - private } \\
\text { University (UPM-Indra } \\
\text { Project) }\end{array}$ & $\begin{array}{l}\text { alliance, as shown in the 30 years of the Project UPM - } \\
\text { Indra }\end{array}$ \\
\hline Telefonica R+D & $\begin{array}{l}\text { Spanish multinational located in the telecommunication } \\
\text { industry }\end{array}$ \\
\hline Tecnalia & $\begin{array}{l}\text { Technology Centre composed by 27 firms and 10 Public } \\
\text { Institutions }\end{array}$ \\
\hline $\begin{array}{l}\text { Aimen (Association for the } \\
\text { Research in Metals from the } \\
\text { North-East) }\end{array}$ & $\begin{array}{l}\text { Technological Centre/ OTRI that comprises more than 100 } \\
\text { firms and associations located in 14 different industries }\end{array}$ \\
\hline Genoma Spain Foundation & $\begin{array}{l}\text { Public Foundation for the promotion of biotechnology in } \\
\text { Spain. The sponsors are the Spanish Ministry of Science and } \\
\text { Innovation the Ministry of Health and Social Affairs, Ministry } \\
\text { of Industry, Tourism and Commerce, Environmental } \\
\text { Ministry, the Government of Navarra and Andalucía }\end{array}$ \\
\hline
\end{tabular}

Source: Bermejo Ruiz (2012)

The relational coordination model can be of interest to reach good results in organizations or organizational processes where high levels of task interdependence, uncertainty and time restrictions, and tacit knowledge are required. In the Science and Technology systems, these circumstances appear. In this paper we have applied the EIRMA (2009) protocol to analyze the degree of relational coordination amongst the various agents taking part in the system.

The Delphi method has been applied. It is a structured communication technique, originally developed as a systematic, interactive forecasting method which relies on a panel of experts. Due to the complexity of the system and the variety or actors in it, this technique has been found the most appropriate one to know in deep the system. The application of the Delphi method has been developed based in two questionnaires, sent twice to the selected agents, first in January 2012, second in March 2012. The first of all was elaborated in collaboration with Prof. Dr. Wim Vanhaverbeke and the OECD, by means of Koen DeBaker Director of STI/SDP. The second one, has been realized by considering the main guidelines of the Responsible Partnering protocol promoted by the European Commission and edited by the EIRMA in 2009 (European Industrial Research Management Association) in consensus with different Institutions of reference in the European R+D+r policy such as the EUA (European University Association), EARTO (European Association of Research and Technology Organizations) and ProTon Europe (European Knowledge Transfer Association).

These surveys where completed in January 2012 by the CEO's of the seven firms that have taken part in the Delphi analysis (table 1), and they describe the open innovation practices in public and private organizations by using public-private collaborative agreements and be able to explain the paradox of high degrees of 
scientific publications facing poor levels of innovation and competitiveness of the Spanish economy. Table 2 shows the main questions included in the survey

Table 2

Questions relevant for the research results

Could you identify any other kind of political push to open innovation practices?

These instruments, have been enough attractive from the organizational point of view to transmit the benefits that the private-public collaboration amongst firms allow?

What is your perception in terms of cooperation? Could you distinguish between collaborative practices and outsourcing ones?

What causes could you identify as organizational promoters so that $R+D$ can internally develop in an extensive way?

Do you manage capabilities dealing with the commercialization of products and services? Managing capabilities linked to the commercialization of products or services are the ones that show a more multidisciplinary character in the organization and it implies the availability of strengths in other functions related to the production, logistic skills, sales forces, marketing or human resources?

Is the Science and Technology System considered as a poor flexible Entity and poor adapted to market needs?

Do you have the proper channel to adapt the system to business reality today?

Do you consider that the communication means organizations use to get into touch with OPIs and SCT are optimally defined and are accessible?

Joint research is often implies a long term period, so to know that the different parts have the previous knowledge is the main justification to establish a collaboration agreement. Does it represent an element of interest for the parts to establish when this knowledge must be available and in what terms?

Which factors do you consider more important for the coordination and control of a collaborative Project?

The interest to publish the results of scientific interest is an essential consideration for universities and OPIs, what is the mechanism that you establish to avoid delays in publications without affecting other important aspects such as the application form for a protective patent? How do you consider the including of confidential information belonging to other parts of the Project?

The right to access to previous information is a critical factor, since it allows warranting the concession of licenses for the stipulated use and that its knowledge fulfill the rights to be spread, How the conditions and restrictions that regulate this information is planned?

The property of the results is an element of a great interest for the stakeholders. Do you consider the joint use of inventions and results of Intellectual Properly by allowing all the parts the joint use of inventions and the resulting IP, or the individual licensing to the parts? By the contrary, is it positive that one of the parts has the individual licensing? Or by the contrary, is it positive that one of the parts has the exclusive right of use in the results by marinating the property?

Source: Bermejo Ruiz (2012)

\section{SWOT analysis}

As main tool for the evaluation of the results we will be applying the SWOT analysis, acronym for Weakness, Threats, Strengths and Opportunities. This analysis has long been applied in prospective analysis over social and participative dynamics. From 1984, it has been each time more often used with applications in many different social and economic environments. This analysis has reached in the last years a great relevance in the strategic planning and in the diagnosis of needs. This methodology is useful when structural transformations are tried and to dynamite the 
change, elaborate new projects in action, and create collaboration networks (Colás, De Pablos, 2004).

Hamel and Prahalad $(1993,1994)$ used the SWOT analysis to analyze different industries. From their point of view, the origin of competitive advantages are found in the essential competencies of the organization, by being the strategic management a collective process of learning that helps to develop and explore distinctive competencies difficult to imitate by competitors.

This focus was re-affirmed by other authors as D'Aveni (1994), Brown and Eisenhardt (1998) and Mohrman, Galbraith and Lawler (1998), who emphasize the need to develop an organizational design that favours the flexible development and the recombination of these capabilities. Therefore, the SWOT analysis will be further applied to offer guidelines to policy makers based in the identification of strengths, weakness, opportunities and threats of the system.

\section{Results}

In this part the results from the empirical analysis are shown. First the results coming from the consensus of the seven organizations asked on the questions included in the Delphi (table 2), and then a general SWOT analysis containing the most important aspects that the seven agents that have taken part in the empirical analysis have stressed is illustrated.

From the application of the Delphi method, a group of questions of high interest for the experts were confirmed (table 2). New questions also appeared and although they were not included at first, they enriched the final analysis (table 3).

\section{Table 3}

New issues that emerged during the Delphi research

The institutional atomization of the SCT and the main role of the regions, Autonomous Communities that do not allow speaking in terms of a Spanish Science and Technological System showing high degrees of Public Interventions

The cultural factors and their impact in the management of the SCT, as the budgetary and the differences shown in relation with the Calvinist ethical societies

The working of university departments and the rotation of research groups, and its influence in the confidentiality of processes and in the creation of tacit knowledge and the relevance that as main asset produces the University System

The importance of the 83 article in the regulation of joint collaboration agreements and the personalization that the universities produce in its application

The plan of university departments to establish stable joint collaboration agreements

The paradox that the available Acts present in the evaluation of university professors merits and their impact in two factors: publications, spin-offs and patents of exploitation

The experience of other countries in the application of other models for the transfer of knowledge from University to firms

The need that the entrepreneurial sector has to dispose of university spin offs that act as service providers of high added value by exploiting the innovations resulted from their research, amongst other reasons, because many times it requires of a support that an university department cannot proportionate unless it is provided by a firm

The impact of the public acquisition of innovation and the reverse transfer as main instruments for the scientific and technological transfer

Source: Authors' work, 2013

This way, the political actions must be oriented to implement a model of innovation that adjusts as much as possible to a triple helix convergent model (Etzkowitz, Leydesdorff, 2000) where the three agents interlinking in the three agents of the system: universities, research centres, firms and Administrations. 
The innovation policies in the EU reveal the effort realized in the last years to develop a strategy that favourites and promotes the establishing of innovation networks (Larn, 2000) or innovation dynamic capabilities (Eisenhardt, Martin, 2000; Tidd, 2000) with the purpose to stress the role that universities and transfer of knowledge centres develop in the innovation strategies of firms to be considered as an important source of knowledge and potential partners (Cooke, 2005, Krüger, 2006). Figure 2 summarizes the main findings of the SWOT analysis.

\section{Discussion}

The key aspect of a knowledge economy is based in a greater dependence in the intellectual capabilities more than in the natural resources, the work or capital. The integration with other resources allows obtaining improvements in the productive process, from the R+D to the production and the relationship with customers (Powell and Snellman, 2004). These changes have been reflected in an increase of the participation related to the GNP attributed to the intangible capital (Abramovitz, David, 1996).

The essential competencies (Prahalad, Hamel, 1990; Day, 1994) are not physical assets, but intangible assets, abilities and technologies (Prahalad, Hamel, 1990) and they are routines, actions, operations that are of tacit nature, ambiguous and idiosyncratic (Polanyi, 1966; Nelson, Winter, 1985; Teece, Pisano, 1994) suggest that the competitive advantage of organizations is based in the established dynamic capabilities in the routines of high qualifications of the processes in organizations, conditioned by its history.

In this context, the Universities develop a main role to generate a knowledge economy, to act as the main agent in the generation of new competencies that answer to these premises in an economic model oriented to services. From the empirical analysis that we have realized in this paper we have proofed that the results are limited since we have found a lack of both integration of capabilities or assignation of resources, and no networks of collaboration or renewal of new ways of thinking, nor capabilities to establish alliances, in the Spanish Science and Technology context.

A Science and Technology model that does not stimulus nor promotes the protection of the intellectual property, inhibits the process of conversion of knowledge from tacit to explicit (Polanyi, 1966; Nonaka, Takeuchi, 1996; Hunt, 1999) since this last allows expressing in a coded way the technologies, products oriented to specific applications and this way, it promotes the establishing of bargaining objectives areas to promote the commercialization, the creation of an efficient knowledge market.

In this sense, we can find a situation where there is a lack of convergence of objectives in the different agents that take part in the systems, since they incentive more their individual objectives as it is stressed in the Agency theory (Alchian, Demtsez, 1972; Jensen, Meckling, 1976; Williamson, 1975, 1996). In the Spanish case, the lack of a common policy at a national level, makes prevail the particular interests of regions and besides, makes flow an incongruent normative that does not offer coherence in the Science and technology System since it does not promote de relationships amongst the agents. Promoting a system that offers higher degrees in relational coordination could make a difference in the process of transfer of knowledge between one country and the countries it collaborates with. 
Figure 2

Results of the SWOT analysis for the Spanish Innovation System

\begin{tabular}{|c|c|c|c|}
\hline 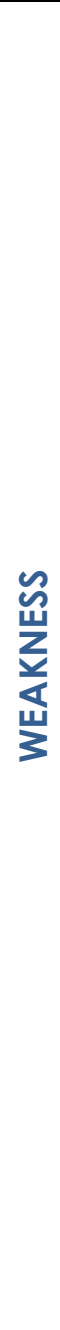 & $\begin{array}{l}\text { STRATEGIC } \\
\text { - Duplicity in the knowledge transfer } \\
\text { structures (OTRIs, Innovation centres, } \\
\text { technological platforms, etc) } \\
\text { - An excess of atomization in the } \\
\text { Spanish Science and Technology } \\
\text { system form the geographical and } \\
\text { disciplinary point of view } \\
\text { High rates of scientific production } \\
\text { (position } 9 \text { in the international scores) } \\
\text { and low levels of competitiveness } \\
\text { (position } 36 \text { in the international scores) } \\
\text { A support for a lineal model of } \\
\text { innovation in universities } \\
\text { CULTURAL } \\
\text { Universities seen as Institutions for the } \\
\text { socialization of knowledge } \\
\text { A low interest of firms and research } \\
\text { centres for patents } \\
\text { A lack of culture to understand the } \\
\text { market of knowledge, which is an } \\
\text { obstacle for the promotion } \\
\text { A lack of values centred in IP and } \\
\text { industrial results } \\
\text { Perception that the collaborative and } \\
\text { stable agreements are a barrier for } \\
\text { innovation } \\
\text { RELATIONAL } \\
\text { Make firms be closer to the SCT to get } \\
\text { public funds for R+D projects } \\
\text { The model firm - research centre is } \\
\text { sustained by a model of } \\
\text { externalization of Works more than in } \\
\text { the cooperation itself } \\
\text { Although there are formal channels to } \\
\text { establish contacts, firms use mainly } \\
\text { informal channels }\end{array}$ & $\begin{array}{l}\text { STRATEGIC } \\
\text { - } \quad \text { The reduction of the R+D public funds } \\
\text { IP as a tool for the reverse transfer } \\
\text { - Universities see in the students a } \\
\text { mechanism for the transfer of } \\
\text { knowledge, facing patents, etc. } \\
\text { The channels to communicate R+D } \\
\text { results are too endogamy for the } \\
\text { scientific community, and therefore, } \\
\text { they lack of access to firms } \\
\text { Contradiction in some aspects of the } \\
\text { legal systems } \\
\text { The legislative reforms prioritize the } \\
\text { index of impact of publications against } \\
\text { the transfer of knowledge } \\
\text { MANAGERIAL } \\
\text { The market of knowledge is } \\
\text { underdeveloped. } \\
\text { A system more centred around } \\
\text { expenses more than in investments } \\
\text { Arbitrary commissions area applied to } \\
\text { the selection of research projects at } \\
\text { universities } \\
\text { CULTURAL } \\
\text { The low levels of R+D externalization of } \\
\text { firms and stable agreements to } \\
\text { promote the reverse transfer } \\
\text { A weak knowledge market, in part due } \\
\text { to the lack of relevance for } \\
\text { understanding the strengths of the } \\
\text { system }\end{array}$ & 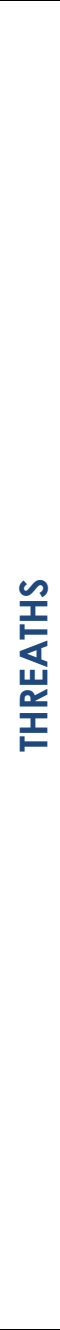 \\
\hline 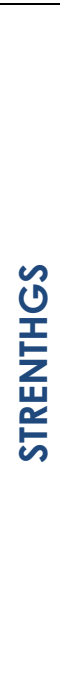 & $\begin{array}{l}\text { STRATEGIC } \\
\text { - Be a country showing high levels of } \\
\text { - } \quad \text { Instientific productional interest in promoting the } \\
\text { triple helix } \\
\text { MANAGERIAL } \\
\text { - } \quad \text { Previous experiences in collaboration } \\
\text { agreements } \\
\text { - A proper legal framework to apply the } \\
\text { responsible partnering } \\
\text { A good disposition of the implied parts } \\
\text { to establish collaboration agreements } \\
\text { by respecting the interests of the parts } \\
\text { RELATIONAL } \\
\text { TOP approach SMEs and big firms in } \\
\text { the Spanish SCT } \\
\text { Good image of firms and OPIs on the } \\
\text { joint benefits of the Ingenio program }\end{array}$ & $\begin{array}{l}\text { STRATEGIC } \\
\text { - } \quad \text { Recent legal frameworks to promote } \\
\text { - } \quad \text { To benizontal and vertical cooperation from the high scientific } \\
\text { production to generate development } \\
\text { (pre-competitive step) and innovation } \\
\text { (basic application) } \\
\text { MANAGERIAL } \\
\text { - Agreement to promote public-private } \\
\text { - Tollaborations and the reverse transfer } \\
\text { entreprene the concept of } \\
\text { Creation of spin off } \\
\text { RELATIONAL } \\
\text { An approach of OPIs to the } \\
\text { entrepreneurial activity and vice-versa }\end{array}$ & 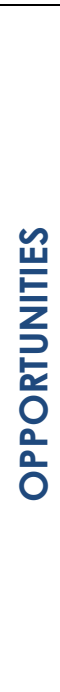 \\
\hline
\end{tabular}

Source: Bermejo Ruiz and De Pablos Heredero (2013) 


\section{Conclusion}

The key aspect of a knowledge economy is the greater dependence on intellectual capabilities rather than the natural resources, work or capital. The integration with other resources allows obtaining improvements in the productive process, from the $\mathrm{R}+\mathrm{D}$ to the production and the relationship with customers. These changes have been reflected in an increase of the participation related to the GNP attributed to the intangible capital.

The essential competencies are not physical assets, but intangible assets, abilities and technologies and they are routines, actions, operations that are of tacit nature, ambiguous and idiosyncratic. Teece and Pisano (1994) suggest that the competitive advantage of organizations is based on the established dynamic capabilities in the routines of high qualifications of the processes in organizations, conditioned by their history. In this context, the universities develop a main role to generate a knowledge economy, to act as the main agent in the generation of new competencies that answer to these premises in an economic model oriented to services.

This way, the political actions must be oriented to implement a model of innovation that adjusts as much as possible to a triple helix convergent model where the three agents interlink in an economic system: Educational Institutions, Business Organizations and Public Administrations.

The innovation policies in the EU reveal the efforts made in the last few years to develop a strategy that favours and promotes the establishing of innovation networks based on the innovative dynamic capabilities with the purpose of stressing the role that universities and knowledge transfer centre's develop in the innovation strategies of the firms to be considered as an important source of knowledge and potential partners.

From this project we have checked the Spanish National System of Innovation from their main agents. The result shows that an effort must be made in the integration of the capabilities that have been developed and the reconfiguration of resources; the networks of collaboration must be redesigned to promote the renewal of new ways of thinking, and establish alliances best oriented to reinforce the transfer of knowledge to the productive sector. Acts must also be oriented to be more coherent with these options.

A Science and Technology model that neither stimulates nor promotes the protection of the intellectual property, inhibits the process of conversion of knowledge from tacit to explicit since this last allows expressing in a coded way the technologies, products oriented to specific applications and this way, it promotes the establishing of bargaining objectives areas to promote the commercialization, the creation of an efficient knowledge market.

In this sense, we can find a situation where there is a lack of convergence of objectives in the different agents that take part in the system, makes keep their individual objectives as it is stressed in the Agency theory (Alchien, Demtsez, 1972; Williamson, 1975, 1996).

This analysis should be extended to the European case where the lack of common policies amongst countries makes prevail the particular interests of regions and besides, makes flow an incongruent normative that does not offer coherence in the European science and technology system since it does not promote de relationships amongst the agents. 


\section{References}

1. Abramovitz, M., David, P. (1996), "Technological Change and the Rise of Intangible Investments: The US Economy's Growth-path in the Twentieth Century", in Foray, D., Lundvall, B. A. (eds), "Employment and Growth in the Knowledgebased Economy", Paris: OECD.

2. Alchian, A. A., Demsetz, H. (1972), "Production, information costs, and economic organization", The American Economic Review, Vol. 62, No. 5, pp. 777-795.

3. Al-Natour, S., Benbasat, I. (2009), "The Adoption and Use of IT Artifacts: A New Interaction Centric Model for the Study of User-Artifact Relationships", Journal of the Association for Information Systems, Vol. 10, No. 9, pp. 661-685.

4. Artopoulos, A. (2006), "Tenaris. Una corporación global desde el sur", available at:

https://www.udesa.edu.ar/files/UAAdministracion/Documentos\%20de\%20Trabajo 159.pdf (17 July 2014).

5. Benkler, Y. (2002), "Coase's Penguin, or Linux and the Nature of the Firms", Yale Law Journal, Vol. 112, No. 3, pp. 369-446.

6. Benkler, Y. (2005), "La nueva economía del código abierto", presentation at TED conference.

7. Benkler, Y. (2006). "The Wealth of Networks. How Social Production Transforms Markets and Freedom", New Haven, London: Yale University Press.

8. Bermejo Ruiz, J. M. (2012), "De la investigación a la innovación: importancia de la gestión de la propiedad intelectual en el sistema científico tecnológico español para la promoción de entornos colaborativos", doctoral dissertation, Universidad Rey Juan Carlos, Madrid, Spain.

9. Bermejo Ruiz, J. M., De Pablos Heredero, C. (2013), "An analysis of the Spanish Science and Technology system", Procedia Technology, Vol. 9, pp. 51 1-517.

10. Brown, S. L., Eisenhardt, K. M. (1998). "Competing on the Edge: Strategy as Structured Chaos", Boston: Harvard Business School Press.

11. Castro, G. M. et al. (2009), "El capital relacional como fuente de innovación tecnológica", Innovar. Revista de Ciencias Administrativas y Sociale, Vol. 19, No. 35, pp. 119-132.

12. Chung, S. A., Singh, H., Lee, K. (2000), "Complementarity, status similarity and social capital as drivers of alliance formation", Strategic Management Journal, Vol. 21, No. 1, pp. 1-22.

13. Colás, B. P., De Pablos, P. J. (2004), "La formación del profesorado basada en redes de aprendizaje virtual: aplicación de la técnica dafo", available at: http://campus.usal.es/ teoriaeducacion/rev_numero_05/n5_art_colas_pablos.ht $\mathrm{ml} /$ (23 March 2011).

14. Conner, K. R., Prahalad, C. K. (1996), "A Resource-Based Theory of the Firm: Knowledge versus Opportunism", Organization Science, Vol. 7, No. 5, pp. 477-501.

15. Cooke, P. (2005), "Regionally Asymetric Knowledge Capabilities and Open Innovation", Research Policy, Vol. 34, No. 8, pp. $1128-1149$.

16. D'Aveni, R. (1994). "Hypercompetiton: Managing the Dynamics of Strategic Maneuvering", New York: Free Press.

17. Day, G. (1994), "The Capabilities of Market-Driven Organizations", Journal of Marketing, Vol. 58, No. 4, pp. 37-52.

18. De Pablos Heredero, C. et al. (2012). "Organization and transformation of information systems at firms", Madrid: ESIC. 
19. Dedrick, J., West, J. (2005), "Why firms adopt Open Source Platforms: A grounded Theory of Innovation and Standards Adoption", available at: http://www.joelwest.org/misq-stds/proceedings/145_236-257.pdf 17 July 2014).

20. Douglas, D. (2003), "Grounded Theory and the "And" in Entrepreneurship Research", Electronic Journal of Business Research Methods, Vol. 2, No. 2, pp. 47170.

21. Douglas, D. (2009), "Entrepreneurship Research and Grounded Theory. Some Methodological Reflections", available at: https://www.staffs.ac.uk/assets/2009\%20David\%20Douglas,\%20'Entrepreneurship\% 20Research\%20and\%20Grounded\%20Theory'_tcm44-21760.pdf (17 July 2014).

22. Doz, Y. L., Olk, P. M., Ring, P. S. (2000), "Formation process of R\&D consortia: which path to take? Where does it lead?", Strategic Management Journal, Vol. 21 , No. 3, pp. 239-266.

23. Drucker, P. F. (1994). "Post-Capitalist Society", New York: Harper Business.

24. EIRMA (2009), "Responsible Partnering. Joining Forces in a World of Open Innovation: Guidelines for Collaborative Research and Knowledge Transfer between Science and Industry". European Industrial Research Management Association Protocol. The Netherlands.

25. Eisenhardt, K. M., Martin, J. A. (2000), "Dynamic capabilities: what are they?", Strategic Management Journal, Vol. 21, No. 10-11, pp. 1105-1121.

26. Ełzkowitz, H., Leydesdorff, L. (2000), "The dynamics of innovation: from National Systems and Mode 2 to a Triple Helix of university industry-government relations", Research Policy, Vol. 29, No. 2, pp. 109-123.

27. Fleming, L., Sorenson, O. (2004), "Science as a map in technological search", Strategic Management Journal, Vol. 25, No. 8-9, pp. 909-928.

28. Galán, J. L., Casanueva, C., Castro-Abancéns, I. (2010), "Las relaciones empresariales: una tipología de redes", Innovar. Revista de Ciencias Administrativas y Sociales, Vol. 20, No. 38, pp. 27-44.

29. Gittell, J. H. (2009). "High Performance Healthcare: Using the Power of Relationships to Achieve Quality, Efficiency and Resilience", New York: Mc GrawHill.

30. Glaser, B. G. (1992). "Basics of grounded theory analysis: Emerge vs. Forcing", Mill Valley: Sociology Press.

31. Glaser, G., Strauss, A. (1967). "The discovery of Grounded Theory: Strategies for qualitative research", New York: Aldine Publishing Company.

32. Goldkuhl, G. (2004). "Conceptual determination when developing a multigrounded theory. Example and Defining ISD method", European Conference on Research Methods in Business and Management, Reading University, UK.

33. Gonzalez-Barahona, J. M. et al. (2001), "Counting Potatoes: the Size of Debian 2.2", Upgrade, Vol. 2, No. 6, pp. 60-66.

34. Hagedroon, J. (1993), "Understanding the Rationale of Strategic Technology Partnering: Interorganizational Modes of Cooperation and Sectoral Differences", Strategic Management Journal, Vol. 14, No. 5, pp. 371-385.

35. Haider, S., De Pablos Heredero, C. (2012), "Determinants of R\&D Cooperation: an Institutional Perspective", Revista de Economía Mundial, No. 32, pp. 239-257.

36. Hamel, G., Prahalad, C. K. (1993), "Strategy as Stretch and Leverage", Harvard Business Review, Vol. 71, No. 2, pp. 75-84.

37. Hamel, G., Prahalad. C. K. (1994). "Competing for the Future", Boston: Harvard Business School Press. 
38. Hunt, S. D. (1999). "A general theory of competition", Thousands Oaks: Sage Publications.

39. International Monetary Fund (1997), "Perspectivas de la economía mundial", Washington, p. 59.

40. Jensen, M. C., Meckling, W. H. (1976), "A theory of the firm: Governance, Residual Claims and Organizational Forms", Journal of Financial Economics, Vol. 3, No. 4, pp. 305-360.

41. Krüger, K. (2006), "El concepto de la Sociedad del Conocimiento", available at: http://www.ub.es/geocrit/b3w-683.htm (25th April 2012).

42. Larn, A. (2000), "Tacit Knowledge, Organizational Learning and Societal Institutions: An Integrated Framework", Organization Studies, Vol. 21, No. 3, pp. 487-513.

43. Locke, K. (2001). "Grounded Theory in Management Research", London: Sage.

44. Lowe, A. (1995), "The basic social processes of entrepreneurial innovation", International Journal of Entrepreneurial Behavior and Research, Vol. 1, No. 2, pp. 54-76.

45. Lundvall, B. (ed.) (1992). "National systems of innovation: towards a theory of innovation and interactive learning", London: Printer Publishers.

46. Malerba, F. (2002), "Sectoral systems of innovation and production", Research Policy, Vol. 31, No. 2, pp. 247-264.

47. Malerba, F. (ed.) (2004). "Sectoral Systems of Innovation. Concepts, Issues and Analyses of Six Major Sectors in Europe", Cambridge: Cambridge University Press.

48. McCormack, A. et al. (2007). "Innovation through Global Collaboration: A New Source of Competitive Advantage", available at: http://www.hbs.edu/faculty/Publication\%20Files/07-079.pdf (17 July 2014).

49. Mohrman, S. A., Galbraith, J. R., Lawler E. E. (1998), "The Challenge of Change. In Tomorrow's Organization: Crafting Winning Capabilities in a Dynamic World", San Francisco: Jossey- Bass.

50. Myers, R. H., Montgomery, D. C., Anderson-Cook, C. M. (2009)." Response surface methodology: process and product optimization using designed experiments (Vol. 705)", London: John Wiley \& Sons.

51. Nelson, R. R., Winter, S. G. (1985). "An evolutionary theory of economic change", Cambridge: Harvard University Press.

52. Nonaka, I., Takeuchi, H. (1996), "A Theory of Organisational Knowledge Creation", International Journal of Technology Management, Vol. 11, No. 7-8, pp. 833-845.

53. Orlikowski, W. J. (1993), "CASE Tools as Organizational Change: Investigating Incre- mental and Radical Changes in Systems Development", MIS Quarterly, Vol. 17, No. 3, pp. 309-340.

54. Orlikowski, W. J., Robey, D. (1991), "Information Technology and the Structuring of Organizations", Information Systems Research, Vol. 2, No. 2, pp. 143-169.

55. Partington, D. (2000), "Building grounded theories of management action", British Journal of Management, Vol. 11, pp. 91-102.

56. Polanyi, M. (1966). "The Tacit Dimension", New York: Anchor Day.

57. Powell, W. W., Snellman, K. (2004), "The Knowledge Economy", Annual Review of Sociology, Vol. 30, pp. 199-220.

58. Prahalad, C., Hamel, G. (1990), "The Core Competence of the Corporation", Harvard Business Review, Vol. 68, No. 3, pp. 79-91.

59. Quintero-Campos, L. J. (2010), "Aportes teóricos para el estudio de un sistema de innovación", Innovar, Vol. 20, No. 38, pp. 57-76. 
60. Senge, P. M. (1990). "La Quinta Disciplina: El Arte y la Práctica de la Organización Abierta al Aprendizaje", Buenos Aires: Granica.

61. Srivastava, R. K., Fahey, L., Christensen, H. K. (2001), "The resource-based view and marketing: The role of market-based assets in gaining competitive advantage", Journal of Management, Vol. 27. No. 6, pp. 777-802.

62. Strauss, A., Corbin, J. M. (1990). "Basics of Qualitative Research: Grounded theory, procedures and techniques", London: Sage.

63. Teece, D. J., Pisano, G. (1994), "The dynamic capabilities of firms: an introduction", Industrial and Corporate Change, Vol. 3, No. 3, pp. 537-556.

64. Teece, D. J., Pisano, G., Shuen, A. (1997), "Dynamics Capabilities and Strategic Management", Strategic Management Journal, Vol. 18, No. 7, pp. 509-533.

65. Tidd, J. (2000), "The competence cycle: translating knowledge into new processes, products and services - Chapter 1", in Tidd, J. (ed.), "From Knowledge management to strategic competencies: measures of technological, market \& organizational innovation", London: Imperial College Press.

66. Tognato, C. (2007), "Construir zonas de intercambio entre la academia y el mercado: una aproximación desde la pragmática cultural", Innovar. Revista de Ciencias Administrativas y Sociales, Vol. 17, No. 30, pp. 7-17.

67. Venkatesh, V. et al. (2003), "User acceptance of information technology: Toward a unified view", MIS Quarterly, Vol. 27, No. 3, pp. 425-478.

68. Werger, G. (2003), "Evolutionary markets and the design of institutional policy", in Pelikan, P., Werger, G. (eds), "The Evolutionary Analysis of Economic Policy", Cheltenham: Edward Elgar.

69. Wheeler, D. (2007), "Why Open Source Software. Look at the Numbers", available at: http://www.dwheeler.com/oss_fs_why.html (30 Jan 2010).

70. Williamson, O. E. (1975). "Markets and hierarchies: analysis and antitrust implications", New York: Pinter.

71. Williamson, O. E. (1996). "The mechanisms of governance", Oxford: Oxford University Press.

72. Zollo, M., Winter, S. G. (2002), "Deliberate learning and the evolution of dynamic capabilities", Organization Science, Vol. 13, No. 3, pp. 339-351.

\section{About the authors}

Carmen de Pablos, PhD, is a Professor in the Business Area at the Rey Juan Carlos University from 1994. She is the Academic Director for the Master's Degree and Doctoral program in Business Administration and Entrepreneurship at the Rey Juan Carlos University and the co-director of the Master's Degree in Project Management, SAP-ERP Systems. She is specialized in information systems and organization complexity. She has chaired Doctoral Dissertations and Projects on the impact of information and communication technologies in organizational performance and presented communications in different international venues and has published 78 articles in specialized journals and 8 books. Author can be contacted at: carmen.depablos@urjc.es

Jose Manuel Bermejo Ruiz; PhD, is co-founder of FringesCT since 2011, one of the world's leading biotechnology companies, e-Business \& Internet of Things (loT). Previously, spent nine years tied to Genzyme, one of the leading biotechnology companies, being responsible for the area of Financial Analysis \& Board of Directors advisor. He was also in Telefónica of Spain in the area of business development markets. He is member of the Scientific Committee ALTEC (Latin-American Association Technology Management) and has published several articles in international journals and conferences. 